\title{
Korkeakouluopiskelijoiden jännittämiskokemusten yhteys opiskelukykyyn
}

\author{
Merja Almonkari \& Kristina Kunttu
}

\section{Tiivistelmä}

Artikkelissa tarkastellaan suomalaisten korkeakouluopiskelijoiden opiskelutilanteissa kokeman sosiaalisen jännittämisen yleisyyttä ja yhteyksiä opiskelijan opiskelukykyyn sekä fyysisen, psyykkisen ja sosiaalisen hyvinvoinnin osatekijöihin. Tutkimuksen fokus on ongelmalliseksi koetussa jännittämisessä.

Tutkimuksen aineistona on hyödynnetty kahta laajaa aiemmin kerättyä tutkimusaineistoa: Korkeakouluopiskelijoiden terveystutkimus 2008 aineistoa (Kunttu \& Huttunen 2009) ja Almonkarin väitöskirja-aineistoa (Almonkari 2007). Molemmat tutkimukset ovat korkeakouluopiskelijoille kohdennettuja kyselytutkimuksia, terveystutkimuksessa vastaajia oli 5086 ja Almonkarin tutkimuksessa 1323. Tässä artikkelissa raportoidaan molemmista aineistoista tehtyjä uusia analyyseja ja esitellään niiden tuloksia.

Korkeakouluopiskelijat kokivat jännittämistä opiskelutilanteissa melko paljon, mutta ongelman se muodosti vain osalle. Lievänä ongelmana jännittämisen koki $36 \%$ miehistä ja $39 \%$ naisista ja suurena ongelmana $11 \%$ miehistä ja $17 \%$ naisista. Yleisintä jännittäminen oli yleisöpuhe- tai esitelmätilanteissa, vieraan kielen puhumisessa ja seminaareissa.

Tutkimus osoitti selkeästi, että ongelmaksi koettu jännittäminen on yhteydessä opiskelijoiden huonoksi kokemaan terveydentilaan ja psyykkiseen pahoinvointiin. Korkeakouluopiskelijoiden arjessa jännittäminen ei rajoitu vain opiskelutilanteisiin, vaan on läsnä kaikessa sosiaalisessa kanssakäymisessä. Yksinäisyys, keskustelutuen puute ja opiskeluyhteisöön kuulumattomuus liittyivät jännittämisongelmaan. Myös kiusaamiskokemukset korostuivat jännittämisen ongelmaksi kokevilla.

Opiskelun ongelmat olivat sitä yleisempiä, mitä suuremmaksi ongelmaksi jännittäminen koettiin. Opiskelu-uupumusmittari osoitti samanlaista yhteyttä jännittämisongelmaan kuin muutkin opiskelukyvyn osa-alueet. Opiskelijoiden toiveet avusta elämänhallinnan ja opiskelun ongelmissa olivat loogisia ja osoittivat opiskelijoiden tiedostavan ongelmiaan.

Asiasanat: jännittäminen, korkeakouluopiskelijat, opiskelijan hyvinvointi, opiskelukyky, opiskeluterveys, viestintäarkuus 


\section{Johdanto}

"Kävin pari kertaa matematiikan ja tietotekniikan kurssien tauludemoissa. Jännitin kädet hikoillen ja sydän pamppaillen sitä, että joudun taululle esittämään tehtävän ja selittämään sen. Onneksi en milloinkaan joutunut...Tosin en aina uskaltanut jännitykseltäni merkitä ainuttakaan tekemääni tehtävää, vaikka olisin tiennyt tehtävän olevan oikein. Parin kerran jälkeen lopetin demoissa käymisen, koska ne olivat liian stressaavia." (yliopisto-opiskelija)

Korkeakouluopiskelijan arki koostuu vuorovaikutuksesta. Siihen kuuluu oppimistehtävien raportointia, ryhmätyötilanteita, luentokeskusteluja, esitelmiä sekä kieli- ja viestintätaitojen harjoituksia. Oppimisen menetelmät ovat vuorovaikutuksen näkökulmasta monipuolistuneet. Varsinaisten opiskelutilanteiden lomassa on mahdollisuus sosiaaliseen kanssakäymiseen opiskelijatovereiden ja muiden korkeakouluyhteisön jäsenten kanssa. Oletamme, että mikäli opiskelija kokee epävarmuutta, arkuutta ja ahdistusta näissä opiskeluelämän tilanteissa, sillä on vaikutuksia hänen hyvinvointiinsa ja opiskelukykyynsä.

Opiskelukyky on 2000-luvulla määritelty työkykyä vastaavaksi laaja-alaiseksi käsitteeksi. Opiskelukyvyn katsotaan perustuvan neljään osa-alueeseen, joita ovat yksilön terveys ja voimavarat, opiskelutaidot, opetus ja opiskeluympäristö. Määrittelytyön yhteydessä tehty laaja kirjallisuuskatsaus osoitti näihin osa-alueisiin liittyvien tekijöiden olevan yhteydessä opiskelijan hyvinvointiin ja opiskelujen sujumiseen. (Kunttu 2008; 2011; Sulander \& Romppainen 2007.) Mielenterveyshäiriöt ovat merkittävä opiskelukyvyttömyyden aiheuttaja (Pylkkänen \& Repo 2006). Psyykkiseen oireiluun liittyy vahvasti puutteellinen sosiaalinen tuki, mutta myös toimeentulon niukkuus sekä riittämättömäksi koettu opiskelun ohjaus tai kokemus väärällä alalla olemisesta (Laaksonen 2005). Opiskelutaidollisilla valmiuksilla on suuri merkitys opiskelujen sujumiseen (Kurri 2006). Kokemus elämänhallinnasta, omien voimien ja kykyjen riittävyydestä sekä sosiaalinen tuki ovat tärkeitä hyvinvointiin ja opiskelun sujumiseen vaikuttavia tekijöitä. Vaikuttamalla opiskelukyvyn kaikkiin ulottuvuuksiin ja niissä tunnistettaviin tekijöihin voidaan edistää opiskelijan opiskelukykyä. (Kunttu 2008, 2011.)

Korkeakouluopiskelijoiden jännittäminen on kiinnostanut monia tutkijoita. Tutkimuskohteina ovat olleet esimerkiksi koetun viestintäarkuuden tai sosiaalisten tilanteiden pelon esiintyminen ja sen vaikutukset. Ilmiö esiintyy useimmin ja vahvimmin esiintymistilanteiksi luokiteltavissa tilanteissa, joissa puhujaan kohdistuu runsaasti huomiota ja hän on mahdollisesti myös arvioinnin kohteena. (ks. Daly ym. 1997; Kunttu ym. 2006; Almonkari 2007). 
Jännittäminen on monitasoinen ilmiö, joka voi kokemustasolla saada monia yksilöllisiä muotoja ja merkityksiä. Jotkut voivat kokea jännittämisen voimakkaasti fyysisinä tuntemuksina (sydän hakkaa, poskia kuumottaa, hikoiluttaa, vapisuttaa), toisille ahdistuksen tai pelon kokemus on päällimmäisenä (hermostuttaa, on levoton, huono olo). Jännittäminen voi merkitä myös positiivista vireytymistä tilanteeseen, virkistymistä ja energisyyden tunteita. Kielteisesti koettuun jännittämiseen liitetään tavallisesti pelon, ahdistuksen ja epävarmuuden tuntemuksia. Usein jännityksen häiritsevyys ja ongelmallisuus liitetään yleisön kokemiseen arvostelevana, jopa tuomitsevana. Kokija saattaa arvioida jännittämisen myös estäneen häntä toteuttamasta itseään, huonontaneen hänen suoritustaan tai eristäneen hänet muista ihmisistä. (Arjas 2002; Almonkari 2007, 92-96, 130-141.) Äärimmillään voidaan puhua ahdistuneisuushäiriöstä tai sosiaalisten tilanteiden pelosta (Martin 2011). Tässä artikkelissa ollaan kiinnostuneita juuri tästä huonosta, kielteisesti koetusta, ongelmallisesta ja haittaavasta jännittämisestä.

\section{Ongelmaksi koettu jännittäminen}

Vuorovaikutuksen kielteiseen kokemiseen liittyviä tieteellisiä käsitteitä on määritelty ja käytetty puheviestinnän alalla vaihtelevasti ja runsaasti (ks. Pörhölä 1995; Valkonen 1995; Sallinen-Kuparinen 1986; Almonkari 2007). Käsitteistä viestintäarkuus (communication apprehension) lienee tunnetuin. McCroskeyn klassisen määritelmän mukaan se tarkoittaa yksilön pelkoa tai ahdistusta, joka liittyy joko todelliseen tai ennakoituun viestintään toisen ihmisen tai ihmisryhmän kanssa. (McCroskey 1977, 78; 1978, 192; 1984, 14). Muita vuorovaikutustilanteissa jännittämistä kuvailevia tieteellisiä käsitteitä ovat mm. sosiaalinen fobia eli sosiaalisten tilanteiden pelko (ks. esim. Leary \& Kowalski 1995; Martin 2011), ujous (ks. esim. Crozier 2001; Henderson \& Zimbardo 2001), vähäpuheisuus (ks. esim. Phillips 1991; 1997) ja viestintähaluttomuus (ks. esim. Burgoon 1978). Kapea-alaisempia käsitteitä ovat esiintymispelko ja esiintymisjännitys (ks. esim. Ayres \& Hopf 1992; Pörhölä 1995). Nämä käsitteet painottavat koetun ongelmallisuuden eri puolia, kuten kontekstia (esiintymisjännitys), pelon ja ahdistuksen kokemista (sosiaalisten tilanteiden pelko) tai puhumisen välttelyä (viestintähaluttomuus), mutta yhteistä niille kaikille on se, että kysymyksessä on inhimilliseen vuorovaikutukseen tai sen ennakoimiseen liittyvä ilmiö. Tässä tutkimuksessa käytetään laajana yläkäsitteenä käsitettä sosiaalinen jännittäminen viittaamaan edellä kuvattuihin, hieman eri asioita painottaviin, mutta yleensä sellaisiin vuorovaikutuksen kokemistapoihin, joihin liittyy monenlaisia kielteisiä tuntemuksia ja ajatuksia sekä fyysistä vireytymistä.

Jännittämiseen liittyvissä käsitteissä kielteinen kokeminen on keskeisellä sijalla. Esimerkiksi Pörhölä määrittelee tilannekohtaisen viestintäarkuuden, josta hän käyttää nimitystä esiintymisjännitys, seuraavasti: " Käsitteellä viitataan esiintymisen synnyttämiin tilannevasteisiin, jotka muodostuvat kielteisistä 
ajatuksista ja tunne-elämyksistä, käyttäytymisen muutoksista ja fysiologisesta vireytymisestä.” (Pörhölä 1995, 19) Määritelmässä kielteisyys liitetään jännittämiseen jo lähtökohtaisesti - vastakohtaa eli myönteisiä ajatuksia ja tunneelämyksiä sisältäviä tilannevasteita Pörhölä nimittää esiintymishalukkuudeksi (Pörhölä 1995, 19). Myös Sallinen-Kuparinen $(1986,17)$ määrittelee viestintäarkuuden $^{1}$ (communication reticence) vuorovaikutukseen liittyvänä kielteisenä tunnetilana, joka voi rajoittaa tai ehkäistä yksilön toimintaa vuorovaikutustilanteessa.

Käytämme tässä tutkimuksessa käsitettä ongelmaksi koettu (sosiaalinen) jännittäminen. Haluamme tällä korostaa sitä, että kokemuksessa keskeistä on kokijan oma tulkinta. Se, mikä on ongelma toiselle, ei ole sitä toiselle. Ongelmaksi voidaan kokea voimakas ahdistuneisuuden kokemus vuorovaikutustilanteissa, jossa yksilö kokee olevansa huomion kohteena. Tyypillistä myös on, että henkilö pelkää sanovansa tai tekevänsä jotakin, joka saa muut pitämään häntä heikkona, tyhmänä tai epäpätevänä (Bourne 1999, 6-7.) Ongelmallisuuteen on liitetty usein sekä fyysinen että psyykkinen jännittyneisyys, mielen levottomuus ja huolestuneisuus, kielteiset ajatukset ja arvioinnit itsestä ja taipumus vältellä tai vetäytyä muiden seurasta. (Crozier 2001, 9-32; Leary \& Kowalski 1995, 4-5; McIntyre \& Thivierge 1995; Toskala 1997.)

Ongelmaksi koettu jännittäminen voi varjostaa opiskelijan elämää monin tavoin. Almonkari (2007) löysi tilastollisen ryhmittelyanalyysin avulla yliopistoopiskelijoiden ryhmän, "vahvasti viestintäarat", jota kuvaa kaikkien opiskelun puheviestintätilanteiden voimakas jännittäminen, vuorovaikutukseen liittyvät huolet, kielteinen käsitys itsestä viestijänä, heikko luottamus omaan selviämiseen, viestintätilanteiden välttely ja taipumus lykätä esilläoloa vaativia kursseja sekä olematon selviytymiskeinojen käyttö.

Seurantatutkimus on osoittanut, että ongelmaksi koettu esiintymisjännitys ja myönteisesti koettu esiintymisvarmuus tai esiintymishalukkuus ovat melko pysyviä ilmiöitä. Opiskelijoista, jotka kokevat esiintymisen ongelmallisena ensimmäisenä opiskeluvuonna, yli puolet kokee samoin viidentenä vuotena. Esiintymisen kokeminen ongelmana on viimeisten vuosikymmenten aikana ja eri vuosien yliopisto-opiskelijoilla ollut melko samalla tasolla, yleensä 27 \%:n ja $33 \%$ :n välillä, todella suureksi ongelmaksi sen on kokenut $4-5 \%$ opiskelijoista. (Kunttu ym. 2006.)

\section{Sosiaalinen jännittäminen ja opiskelu}

Yhdysvaltalaisten viestintäarkuuden tutkimusten perusteella tiedetään, että erittäin viestintäarat opiskelijat menestyvät viestintähalukkaampia huonom-

${ }^{1}$ Suomessa on käytetty termiä viestintäarkuus sekä englanninkielisten communication reticence että communication apprehension -käsitteiden suomenkielisenä vastineena (ks. esim. Sallinen-Kuparinen 1986, 233; Pörhölä 1995, 18). 
min opinnoissaan, saavat alhaisempia pisteitä pääsykokeissa, omaavat kielteisiä opiskeluasenteita, pärjäävät huonommin luokkahuoneen vuorovaikutustilanteissa, kokevat helpommin opiskelu-uupumusta, keskeyttävät kursseja useammin ja keskeyttävät yliopisto-opinnot useammin (Boohar \& Seiler 1982; Erickson \& Gardner 1992).

Suomessa jännittämisen yhteyksiä opiskeluun on tutkittu sekä tilastollisin menetelmin että laadullisesti opiskelijoiden itsearvioinnin perusteella. Tutkimuksissa on aiemmin löydetty tilastollinen yhteys mm. opiskelijan kokeman sosiaalisen jännittämisen ja uupumusasteisen opiskeluväsymyksen (SalmelaAro 2009, 31), opiskelussa koettujen ongelmien kuten opetuksen seuraamisen, ryhmätyöskentelyn, omatoimisuutta vaativien tehtävien aloittamisen ja loppuun saattamisen sekä tulevaisuuden suunnittelemisen (Almonkari 2007, 107) välillä. Myös kiusatuksi tulemisen kokemukset, heikko viestijäkuva, aikaisemmat kielteiset vuorovaikutuskokemukset, yksinäisyys ja pieni lähipiiri sekä terveyden ongelmat on liitetty sosiaaliseen jännittämiseen tilastollisesti löytyneen yhteyden vuoksi (Almonkari 2007, 106-116).

Opiskelijoita on pyydetty myös itse arvioimaan jännittämisen vaikutuksia. Kun kolmannen, neljännen ja viidennen vuoden yliopisto-opiskelijoita pyydettiin kyselytutkimuksessa arvioimaan oman jännittämisensä vaikutuksia opiskeluun, enemmistö ( $76 \%$ ) oli sitä mieltä, että jännittäminen ei ole suoranaisesti vaikuttanut opiskelujen etenemiseen tai tutkinnon valmistumiseen mitenkään. Loput, noin neljäsosa, raportoi jännittämisellä olleen esimerkiksi seuraavia vaikutuksia: jännitys kuormittaa henkisesti (6\%), kursseja valitaan sen perusteella, sisältävätkö ne esiintymistilanteita tai viereen kielen puhumista (6\%) tai esiintymistä vaativia seminaareja lykätään myöhempää opiskeluvaiheeseen $(6 \%)$. Jotkut kokevat jännittämisen edistävän opintoja (3\%), toiset taas hidastavan niitä (2\%). (Almonkari 2007, 124-126.)

Vaikka sekä yliopistojen että ammattikorkeakoulujen opiskelijat kokevat voivansa hyvin, heillä on runsaasti erilaista oireilua ja psyykkisiä vaikeuksia. Opiskelijoiden psyykkiset ongelmat ilmenevät usein unihäiriöinä, jatkuvan ylirasituksen kokemisena, masennuksen tunteena sekä vaikeuksina suunnitella tulevaa. Luottamuksellisen keskustelutuen puutetta esiintyy miehistä kolmanneksella ja naisista $16 \%$ :lla. Korkeakouluopiskelussa koetaan paljon irrallisuutta, sillä kolmannes ei koe kuuluvansa mihinkään opiskeluun liittyvään ryhmään. Ajanhallinnassa on runsaasti ongelmia, sillä $15 \%$ opiskelijoista kokee "hukkuvansa opintoihin liittyvään työmäärään". Opiskelijat kertovat myös usein ohjauksen puutteesta opiskeluissa. (Kunttu \& Huttunen 2009.)

Puheviestinnän tieteenalan näkökulmasta kiinnostava tulos näissä aiemmissa tutkimuksissa on opiskelun vuorovaikutustilanteissa koetun jännittämisen runsas esiintyminen sekä jännittämisen yhteys opiskelijan hyvinvoinnin osatekijöihin. Aiemmissa tutkimuksissa ei ole kuitenkaan tarkasteltu nimenomaan ongelmaksi koetun jännittämisen yhteyksiä opiskelijoiden hyvinvoin- 
tiin. Tämän artikkelin fokus on ongelmalliseksi koetussa jännittämisessä, koska sen voi olettaa kuormittavan opiskelijaa ja vähentävän hänen hyvinvointiaan ja opiskelukykyään.

\section{Tutkimuksen tavoitteet ja tutkimuksen toteuttaminen}

\section{Tutkimuksen tavoitteet}

Tämän tutkimuksen tavoitteena on raportoida suomalaisten korkeakouluopiskelijoiden ongelmaksi koettua jännittämistä opiskelun vuorovaikutustilanteissa ja tutkia ongelmaksi koetun jännittämisen yhteyksiä opiskelukyvyn ja hyvinvoinnin osatekijöihin. Yhteyksiä selvittämällä pyritään saamaan lisätietoa sosiaalisesta jännittämisestä ilmiönä ja sen vaikutuksista opiskeluun ja opiskelijan hyvinvointiin. Tietoa voidaan hyödyntää jännittämisen ongelmalliseksi kokeville opiskelijoille suunnatuissa tukitoimissa, esimerkiksi viestinnän ja vieraiden kielten erityiskursseilla, vertaistukiryhmissä ja opiskeluterveydenhuollossa.

\section{Tutkimuksen aineisto}

Tutkimuksen aineistona käytetään kahden korkeakouluopiskelijoille kohdennetun kyselytutkimuksen aineistoa: Korkeakouluopiskelijoiden terveystutkimus 2008 aineistoa (Kunttu \& Huttunen 2009) ja Almonkarin väitöskirja-aineistoa (2007). Korkeakouluopiskelijoiden terveystutkimus 2008:n kohdejoukkona olivat alle 35-vuotiaat perustutkintoa suorittavat suomalaiset korkeakouluopiskelijat. Otoksen koko oli 9978 opiskelijaa, joista $45 \%$ oli miehiä (taulukko 1). Kokonaisvastausprosentti oli $51 \%$ ja vastanneet edustivat hyvin kohdejoukkoa kaikkien taustamuuttujien osalta.

Almonkarin väitöstutkimuksen otos oli Jyväskylän yliopiston kolmannen, neljännen ja viidennen vuoden opiskelijat (3701), joista kyselyyn vastasi 1323 . Sähköisen kyselyn vastausprosentiksi tuli 35,7 \%. Kolme neljäsosaa $(75,5 \%)$ vastaajista oli naisia, yksi neljäsosa $(24,5 \%)$ miehiä. Vastaajat edustivat kaikkia yliopiston tiedekuntia.

\section{Tutkimusmenetelmät}

Almonkarin väitösaineistosta tehtiin uusi sisällönanalyysi vastausaineistosta, joka oli saatu seuraavan avoimen kysymyksen avulla: "Onko jännittäminen mielestäsi vaikuttanut siihen, miten opintosi ovat edenneet tai milloin tutkintosi valmistuu? Miten?". Vastauksista etsittiin erityisesti opiskelijoiden fyysiseen, psyykkiseen ja sosiaaliseen hyvinvointiin sekä opiskeluun liittyviä opiskelukyvyn osatekijöiden mainintoja.

Korkeakouluopiskelijoiden terveystutkimus 2008:ssa kysyttiin jännittämistä seuraavasti: "Onko opiskelutilanteissa jännittäminen sinulle mielestäsi ongelma?" Alakohtina oli viisi erityyppistä tilannetta ja avovastausmahdollisuus 
muu (alakohdat ks. kuvio 1). Vastausvaihtoehtoina oli 0) en jännitä, 1) jännitän joskus, ei ongelma, 2) lievä ongelma, 3) suuri ongelma. Vastausten jakaumat on esitelty perusraportissa. Tätä tutkimusta varten kysymyksestä muodostettiin uusi, kaikki alakohdat huomioiva mittari jännittämistä kuvaavaksi peruskysymykseksi. Opiskelijan katsottiin kokevan ongelmallista jännittämistä, jos hän oli vastannut minkä tahansa tilanteen kohdalla 2 (lievä ongelma) tai 3 (suuri ongelma). Analyyseissä käytettiin jaottelua $0+1 / 2$ / 3. Jännittämisen yhteyttä opiskelukykyyn tutkittiin ristiintaulukoimalla tämä uusi jännittämisen peruskysymys eri opiskelukyvyn osatekijöitä mittaavien muuttujien kanssa. Nämä opiskelukyvyn muuttujat ja niiden jakaumat on esitelty perusraportissa.

Opiskelukyvyn osatekijöistä kartoitettiin koettua fyysistä ja psyykkistä terveyttä, sosiaalista hyvinvointia ja opiskelun kokemuksia. Fyysisen terveyden kysymyksinä olivat koetun terveyden lisäksi yleisoireet (huomioitu päänsärky, väsymys, huimaus) ja vatsaoireet. Henkistä hyvinvointia kartoitettiin useilla kysymyksillä: psyykkiset oireet (huomioitu: nukahtamisvaikeudet, keskittymisvaikeudet, jännittyneisyys, masentuneisuus, ahdistuneisuus), psyykkistä hyvinvointia mittaava General Health Questionnaire (GHQ12) ja kokemukset tulevaisuudesta, mielialasta sekä omista voimista ja kyvyistä. GHQ12-mittarissa on 12 kysymystä, joissa jokaisessa neljä vastausvaihtoehtoa skaalalla 1-4. Jos on vastannut neljään tai useampaan kysymykseen vaihtoehdoilla 3 tai 4, se osoittaa psyykkisten ongelmien olemassaoloa. Mittaria käytettiin myös jatkuvana muuttujana.

Sosiaaliseen hyvinvointiin liittyvät kysymykset olivat yhdessäolo ystävien kanssa, yksinäisyys ja keskustelutuen saaminen, opiskeluryhmään kuuluminen ja kiusaamiskokemukset koulu- ja opiskeluaikana. Opiskeluun liittyviä opiskelukyvyn osatekijöitä olivat kokemus otteen saamisesta opiskeluun, opintomenestyksestä, omalla opiskelualalla olemisesta sekä opintoihin saadusta ohjauksesta ja neuvonnasta. Mukana oli myös opiskelu-uupumusmittari, joka koostuu yhdeksästä kysymyksestä (Salmela-Aro 2009). Sen osa-alueita ovat ekshaustio, kyynisyys ja riittämättömyys, joita myös tarkasteltiin erikseen. Näitä käsiteltiin jatkuvina muuttujina: mitä suurempi keskiarvo, sitä enemmän uupumusta. Lisäksi tiedusteltiin, minkä tyyppisissä asioissa opiskelija haluaisi apua terveydenhuollolta tai oppilaitokselta.

Tuloksia tarkasteltiin suorina jakaumina sekä ristiintaulukoimalla koulutussektorien ja sukupuolten suhteen. Analysointi tehtiin ensin erikseen ammattikorkeakoulujen ja yliopistojen miehille ja naisille, mutta erot olivat kaikissa kohdissa samansuuntaisia, joten ammattikorkeakoululaisten ja yliopisto-opiskelijoiden aineistot yhdistettiin. Tilastollisena testinä käytettiin luokiteltujen muuttujien ristiintaulukoinnissa Cochran-Mantel-Haenzel testiä ja GHQ12:n ja opiskelu-uupumuksen keskiarvojen tarkastelussa varianssianalyysia. Merkitsevyystason rajana käytettiin $p=0,001$. Merkitsevyystestaus tehtiin kunkin muuttujan osalta taulukkotasolla. Koska jännittämiskysymys on kolmiluokkainen, 
niin testi ei suoraan kerro, minkä ryhmien välinen ero on merkitsevä. Eron merkittävyyden arvioimiseksi esitetään sen vuoksi aina myös eri jännittäjäryhmien prosenttiosuudet tai keskiarvot tarkasteltavan muuttujan kohdalla. Analyyseissä verrataan riviprosentteja eri jännittäjäryhmien välillä (ei, lievä, suuri ongelma) ja tarkastelluista muuttujista kuvioihin on otettu aina huonosti voivien osuudet.

\section{Tulokset}

\section{Opiskelutilanteissa jännittämisen yleisyys}

Ongelmaksi koettu jännittäminen opiskelutilanteissa oli naisilla hieman tavallisempaa kuin miehillä. Kaikista vastanneista miehistä $53 \%$ ja naisista $44 \%$ ei kokenut jännittämistä ongelmana missään opiskelutilanteessa. Lieväksi ongelmaksi sen arvioi $36 \%$ miehistä ja $39 \%$ naisista ja suureksi ongelmaksi $11 \%$ miehistä ja $17 \%$ naisista (ks. taulukko 1).

Taulukko 1. Jännittäminen jossakin opiskelutilanteessa, koulutussektoreittain ja sukupuolittain (\%).

\begin{tabular}{|r|c|c|c|c|c|c|}
\cline { 2 - 7 } \multicolumn{1}{c|}{} & \multicolumn{3}{c|}{ miehet } & \multicolumn{3}{c|}{ naiset } \\
\cline { 2 - 7 } \multicolumn{1}{c|}{} & $\begin{array}{c}\text { amk } \\
\mathrm{N}=853\end{array}$ & $\begin{array}{c}\text { yo } \\
\mathrm{N}=986\end{array}$ & kaikki & $\begin{array}{c}\text { amk } \\
\mathrm{N}=1456\end{array}$ & $\begin{array}{c}\text { yo } \\
\mathrm{N}=1740\end{array}$ & kaikki \\
\hline ei ongelma & 51 & 56 & 53 & 43 & 45 & 44 \\
\hline lievä ongelma & 37 & 34 & 36 & 39 & 38 & 39 \\
\hline suuri ongelma & 12 & 10 & 11 & 18 & 17 & 17 \\
\hline
\end{tabular}

Kuten kuviosta 1 ilmenee, yleisintä jännittäminen oli yleisöpuhe- tai esitelmätilanteissa, vieraan kielen puhumisessa ja seminaareissa, joissa neljännes tai jopa kolmannes opiskelijoista raportoi sen olevan lievä tai suuri ongelma. Suuri ongelma jännittäminen oli noin $8 \%$ :lle opiskelijoista näissä tilanteissa. Tenttijännitystä pidetään tavallisena, mutta tutkimuksen mukaan tenteissä jännittäminen oli suuri ongelma vain yhdelle sadasta opiskelijasta ja lievä $8 \%$ :1le. Opettajan tai ohjaajan kanssa keskusteleminen ei ollut iso ongelma kuin erittäin harvoille (ks. kuvio 1).

\section{Jännittämisen yhteys opiskelukyvyn osatekijöihin}

Jännittäminen oli tilastollisesti merkitsevästi yhteydessä koettuun terveydentilaan ja oireiluun. Opiskelijat, joilla jännittäminen oli suuri ongelma, kokivat terveydentilansa huonoksi tai oireilivat päivittäin noin kaksi kertaa niin yleisesti kuin ne, joille jännittäminen ei ollut ongelma (ks. kuvio 2). 


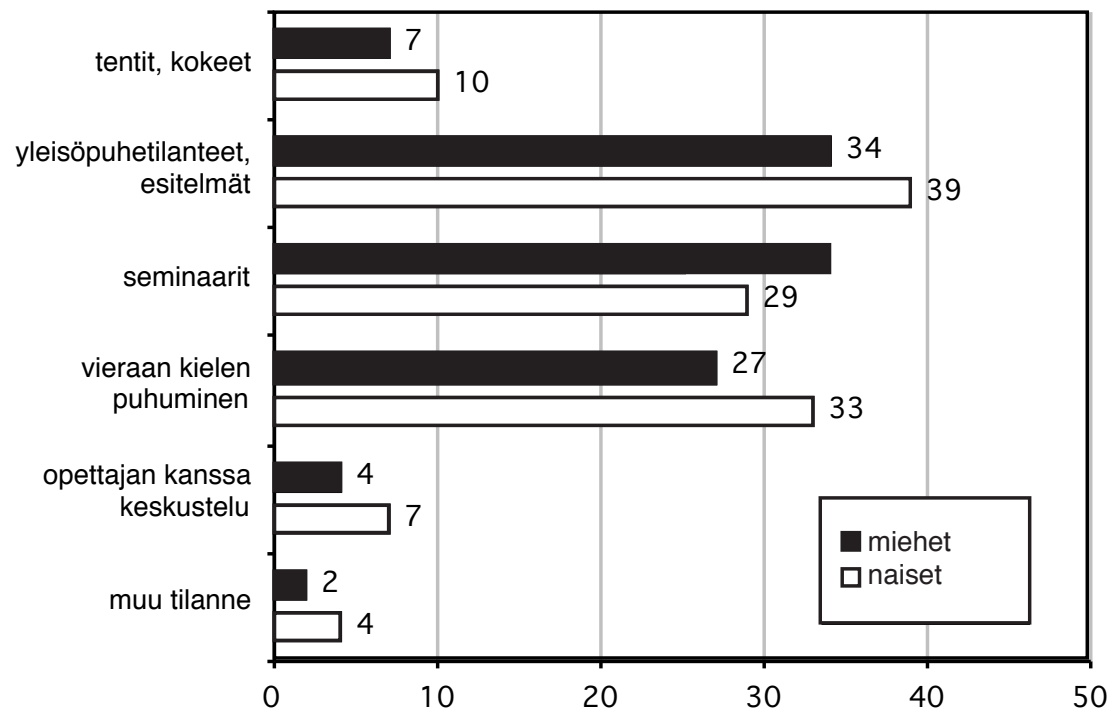

Kuvio 1. Ongelmaksi koettu jännittäminen eri opiskelutilanteissa, lievä tai suuri ongelma (\%), sukupuolittain.

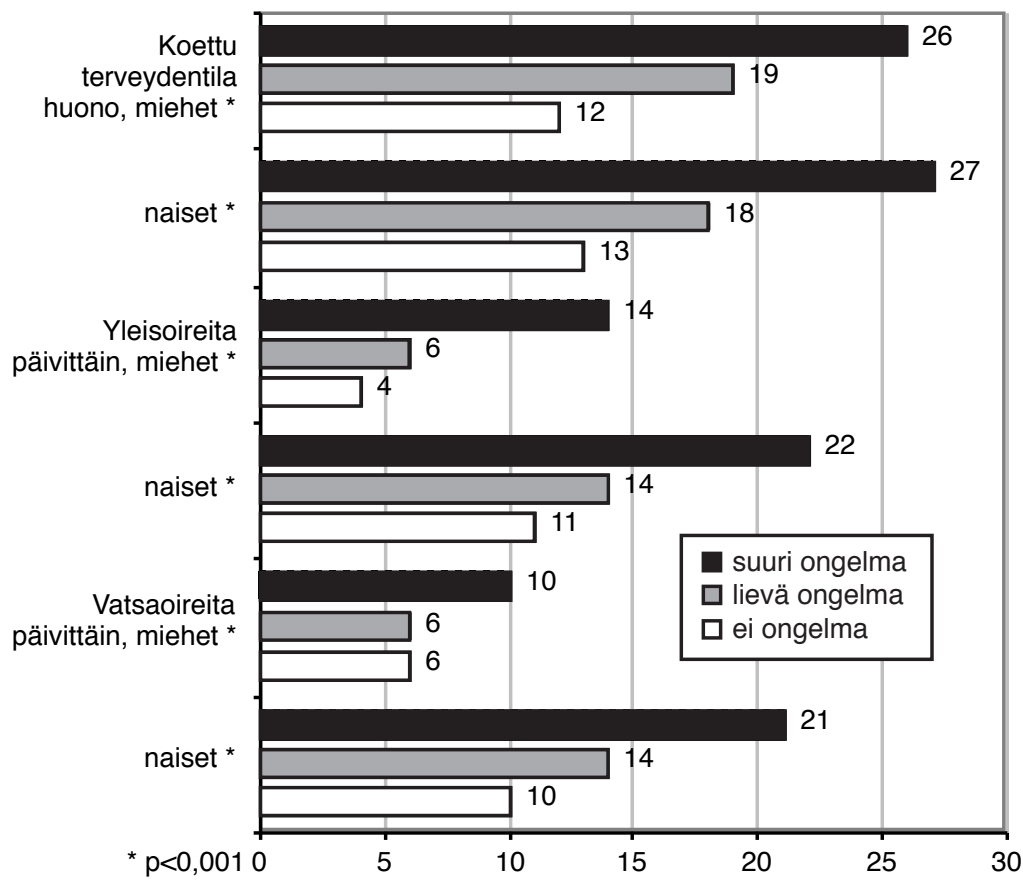

Kuvio 2. Jännittämisen yhteys koettuun terveydentilaan, yleis- ja vatsaoireisiin (\%). 
Jännittämisongelman kokemuksella oli tilastollisesti merkitsevä yhteys kaikkiin tutkittuihin psyykkisen hyvinvoinnin mittareihin (ks. kuvio 3). Jännittämisongelmista kärsivillä miehillä psyykkisiä oireita, kuten unihäiriöitä, masentuneisuutta ja ahdistuneisuutta oli yli kolminkertaisesti ongelmattomiin verrattuna. Psyykkistä hyvinvointia mittaavaa GHQ12-seulaa tarkasteltiin myös jatkuvana muuttujana pistearvojen keskiarvona. Keskiarvot olivat eri jännittämiskokemusryhmissä (ei, lievä, suuri) miehillä seuraavat: 1,$5 ; 2,1$ ja 3,3 ja vastaavasti naisilla 2,3; 3,0 ja 4,0 ( $\mathrm{p}<0,0001$ molemmilla).

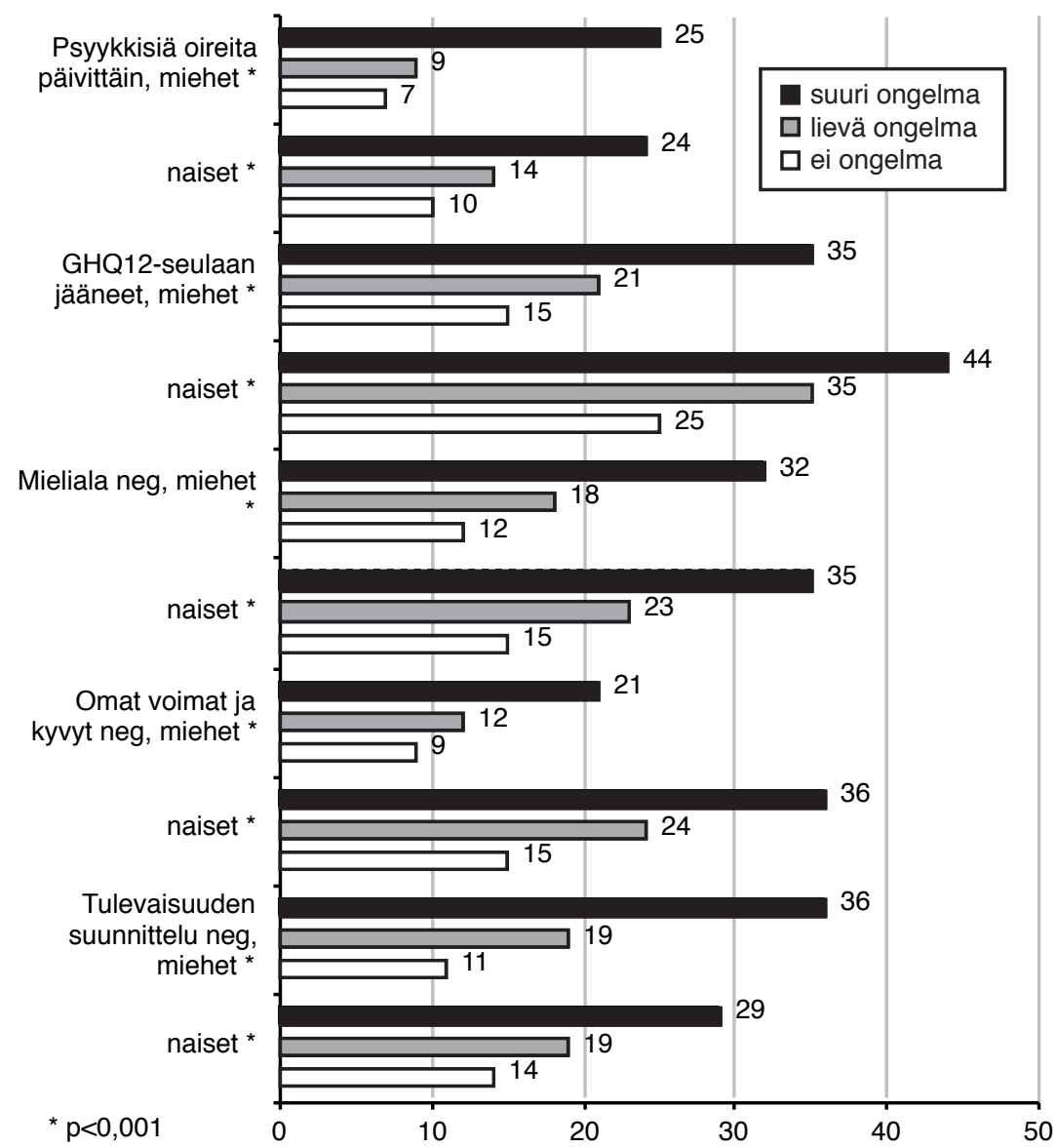

Kuvio 3. Jännittämisen yhteys psyykkiseen hyvinvointiin (\%).

Jännittäminen ei luonnollisesti rajoitu vain opiskelutilanteisiin, vaan on läsnä kaikessa sosiaalisessa kanssakäymisessä. Tässä tutkimuksessa se näkyi ristiin- 
taulukoitaessa jännittämisryhmiä eri sosiaalisen hyvinvoinnin mittarien kanssa. Kussakin tarkastelussa todettiin tilastollisesti merkitsevä ero eri jännittäjäryhmien välillä (ks. kuvio 4). Jännittämistä suurena ongelmana pitävät kärsivät keskustelutuen puutteesta kaksi kertaa ja kokivat yksinäisyyttä viisi kertaa niin yleisesti kuin jännittämisen suhteen ongelmattomat. Opiskeluryhmään kuulumattomuus on yleistä opiskelijoilla ja tämä korostui jännittäjillä niin, että hieman yli puolet jännittämistä suurena ongelmana pitävistä ei kokenut kuuluvansa - tai ei osannut sanoa kuuluuko - mihinkään opiskeluun liittyvään ryhmään.

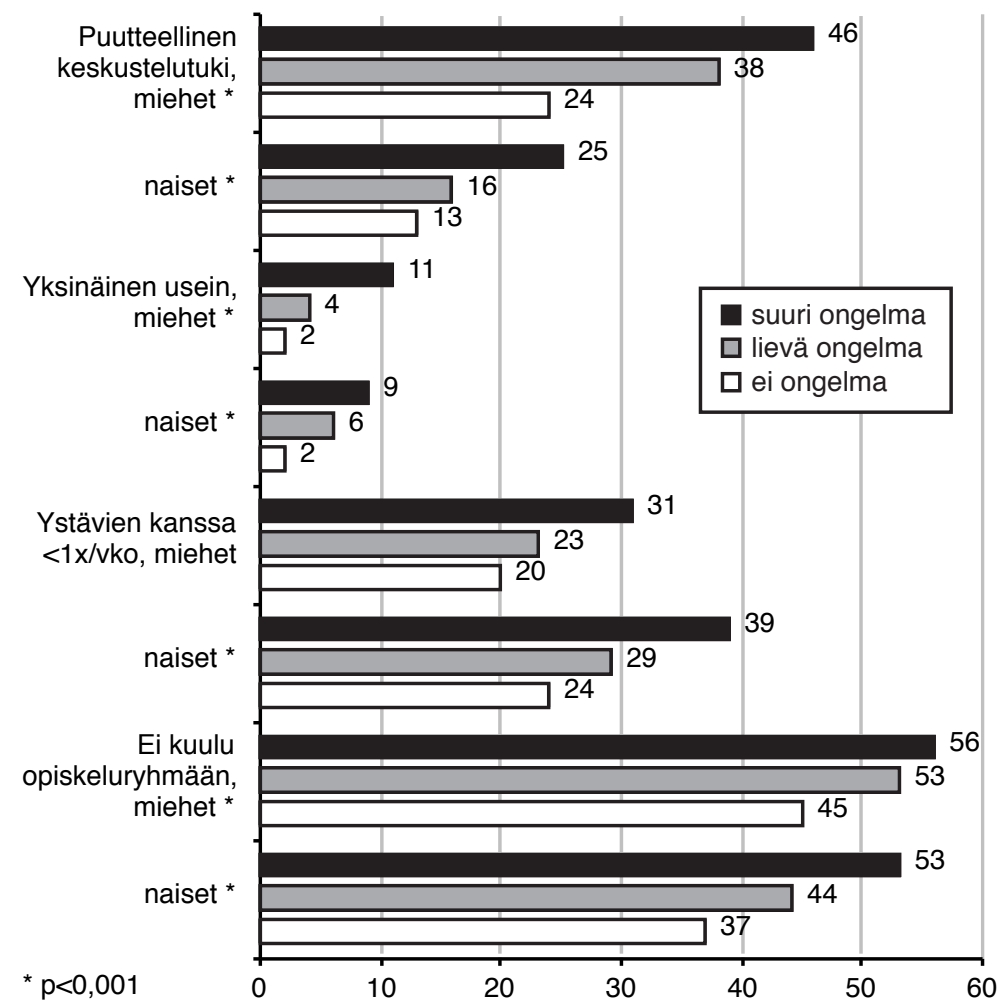

Kuvio 4. Jännittämisen yhteys sosiaaliseen hyvinvointiin (\%).

Kouluaikaiset kiusaamiskokemukset ovat korkeakouluopiskelijoilla varsin yleisiä, mutta jännittämisen ongelmaksi kokevilla ne korostuivat. Jännittämisen suureksi ongelmaksi kokevista miehistä $25 \%$ oli kokenut koulukiusaamista useita vuosia, kun osuus lievän ongelman ja ongelmattomien ryhmissä oli $15 \%$ ja $14 \%$. Naisilla vastaavat osuudet olivat $20 \%, 14 \%$ ja $11 \%$ (p<0,001 sekä miehillä että naisilla). Opiskeluaikana kiusaaminen oli harvinaisempaa, mutta jännittämisen yhteys opiskeluaikaisiin kiusaamiskokemuksiin oli samansuun- 
tainen kuin koulukiusaamiskokemuksissa. Jännittämisen isoksi ongelmaksi kokevista miehistä $8 \%$ ja naisista $9 \%$ oli kokenut tulleensa kiusatuksi melko tai hyvin paljon opiskeluaikanaan. Muissa ryhmissä vastaava osuus oli 5 - $6 \%$ ( $\mathrm{p}<0,001$ sekä miehillä että naisilla).

Jännittämisellä oli myös tilastollisesti merkitsevä yhteys kaikkiin tutkimuksessa olleisiin opiskelua tutkiviin kysymyksiin siten, että mitä suuremmaksi ongelmaksi jännittäminen koettiin, sitä negatiivisempana vastaajat raportoivat opiskelutekijät.

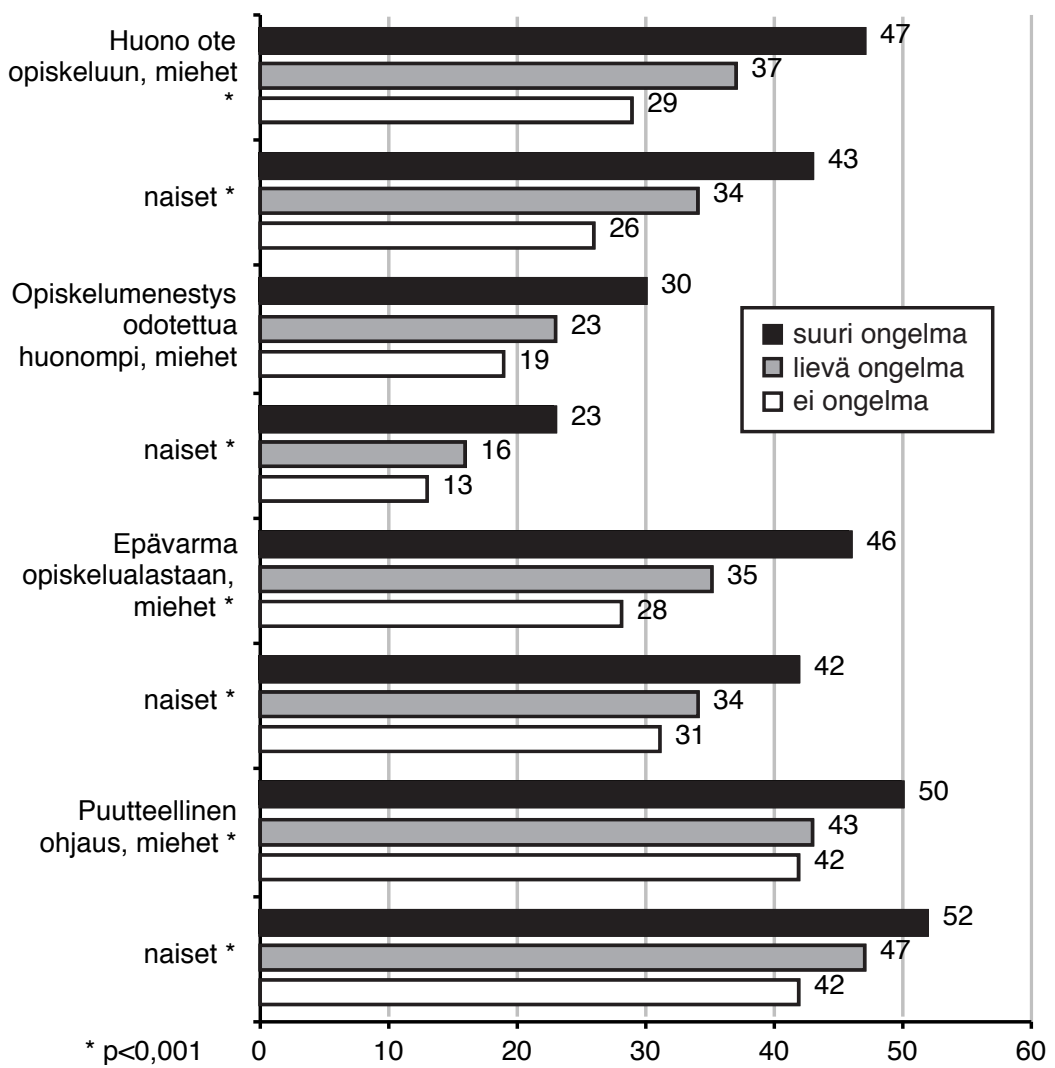

Kuvio 5. Jännittämisen yhteys opiskelutekijöihin.

Opiskelu-uupumusmittari osoitti samanlaista yhteyttä jännittämisongelmaan kuin muutkin opiskelukyvyn osa-alueet. Kokonaisuupumuksen ja sen osaalueiden keskiarvot olivat sitä suurempia, mitä suuremmaksi ongelmaksi opiskelija jännittämisen koki (taulukko 2). 
Taulukko 2. Opiskelu-uupumusmittarin ja sen osa-alueiden keskiarvot.

\begin{tabular}{|r|c|c|c|c|c|c|c|c|}
\hline \multirow{2}{*}{ Jännittäminen } & \multicolumn{2}{|c|}{ ekshaustio* } & \multicolumn{2}{|c|}{ kyynisyys $^{*}$} & \multicolumn{2}{c|}{ riittämättömyys $^{*}$} & \multicolumn{2}{c|}{ kokonaisuupumus $^{*}$} \\
\cline { 2 - 9 } & miehet & naiset & miehet & naiset & miehet & naiset & miehet & naiset \\
\hline ei ongelma & 9,1 & 10,6 & 6,8 & 6,7 & 5,1 & 5,5 & 21,0 & 22,8 \\
\hline lievä ongelma & 10,5 & 11,9 & 7,5 & 7,4 & 5,8 & 6,2 & 23,9 & 25,5 \\
\hline suuri ongelma & 12,0 & 13,2 & 8,9 & 8,5 & 6,7 & 7,0 & 27,7 & 28,7 \\
\hline
\end{tabular}

* kaikissa tarkasteluissa $p<0,001$

\section{Jännittämisen yhteys opiskelukykyyn opiskelijoiden arvioimana}

Tilastollinen yhteys opiskelukyvyn osatekijöiden ja ongelmaksi koetun jännittämisen näyttää olevan selkeä ja vahva. Opiskelijoiden omaa arviointia yhteydestä pyrittiin selvittämään myös tutkimalla tarkemmin Almonkarin väitöskirja-aineistoa seuraavan kysymyksen vastausten suhteen "Onko jännittäminen mielestäsi vaikuttanut siihen, miten opintosi ovat edenneet tai milloin tutkintosi valmistuu? Miten?". Vastauksista etsittiin erityisesti opiskelukykyyn liittyvien fyysisen, psyykkisen ja sosiaalisen hyvinvoinnin sekä opiskelukyvyn osatekijöiden mainintoja.

Vastausten tarkastelu osoitti ensinnäkin, että neutraalin "Ei ole vaikuttanut."vastauksen lisäksi esiintyi jyrkempiä kieltoja, joissa heijastuu opiskelijan suhtautuminen jännittämiseen. Vastaukset saattavat ilmentää opiskelijoiden näkemystä jännittämisestä vähämerkityksisenä ilmiönä, joka ei vaikuta opiskeluun tai mahdollisesti vaativaa ja ankaraa suhtautumista itseen. Opintojen eteneminen on näiden vastaajien mielestä tärkeintä, tapahtui mitä tahansa. Joidenkin mielestä jännittäminen ei ole sopivaa yliopisto-opiskelijalle vaan liittyy nuorempiin ihmisiin. Seuraavassa muutamia esimerkkejä yliopisto-opiskelijoiden vastauksista: (Onko jännittäminen mielestäsi vaikuttanut siihen, miten opintosi ovat edenneet...)

"Ei missään tapauksessa. Opintoni kiilaavat kaiken jännittämisen yli. En edes anna itselleni mahdollisuutta vedota moiseen syyhyn opintojen lykkäämisessä."

"ei (yliopisto-opiskelijoiden pitäisi varmaan olla sen verran kypsiä ettei tällaisia asioita tarvitsisi miettiä)"

Toiseksi, uuden sisällönanalyysin tuloksena löytyi myös useita vastauksia, joissa opiskelija aluksi kieltää jännittämisen vaikuttaneen varsinaisesti opiskelun etenemiseen, mutta heti jatkoksi kertoo monista jännittämisen kielteisistä vaikutuksista arkipäivään. Seuraavissa esimerkeissä nousee esille monenlaisia hyvinvoinnin puuttumisen piirteitä, muiden muassa unettomuus, muun elämän velvollisuuksien karsiminen, stressi ja huoli tulevaisuudesta. 
"Ei ole vaikuttanut. Unettomia öitä olen kyllä viettänyt. Olen myös karsinut muita velvollisuuksia pysyäkseni rauhallisena ja ollakseni stressaantumatta yhtään enempää kuin on "pakko"."

"Jännittäminen ei ole vaikuttanut opintojen edistymiseen, mutta se aiheuttaa jatkuvaa stressiä ja huolta tulevaisuudesta."

Kolmanneksi, jännittäminen kuormittaa ja aiheuttaa esiintymistä vaativien kurssien välttelyä ja lykkäämistä. Vastauksissa opiskelijat selittävät syyksi esiintymiskokemukseen liittyviä kielteisiä piirteitä: esiintyminen on "paha paikka", se stressaa, on ahdistavaa, on vaikeaa, pelottaa, hämmentää ja aiheuttaa noloja tilanteita. Jännittäminen liittyy opiskelijoiden vastauksissa myös heikkoon itsetuntoon, huonommuuden tunteeseen ja masennukseen, kuten seuraavissa vastauksissa.

"Olen siirtänyt esiintymistä vaativia kursseja tuonnemmas. Esiintymisjännitys on ylipäänsä vaikuttanut itsetuntoon - toisaalta heikko itsetunto on ruokkinut esiintymisjännitystä."

"On vaikuttanut huomattavan paljon. Olen ollut masentunut, ja opinnot ovat viivästyneet parikin vuotta. Graduseminaariin en uskaltanut mennä, kun koin olevani niin huono. Osittain samasta syystä gradu on vieläkin tekemättä.”

Neljänneksi, jännittämisen koettiin heikentävän suoritusta ja esimerkiksi vähentävän seminaarissa uskottavuutta asiantuntijana. Ongelmalliseen jännittämiseen liitettiin myös vaikeuksia ohjaustilanteiden vuorovaikutuksessa. Laitoksen henkilökunnan kohtaaminen pelottaa ja ohjauksen hakeminen jännittää ja arveluttaa. Moni jääkin opinnäytetöidensä kanssa yksin, koska ei yksinkertaisesti uskalla ottaa yhteyttä ohjaajaan.

"Gradun kanssa on kyllä vähän rankkaa käydä puhumassa proffan luona. Sitä yhä jännitän. Tiedä lie vaikuttaako sitten siihen? Tuntee itsensä melko tyhmäksi. Proffa on kyllä hyvin avulias ja asiallinen, joten siitä ei voi valittaa (kauhukertomukset).”

"Kyllä tavallaan siksi, että pelkään ja pidän erittäin stressaavana graduohjaajan ja yleensäkin laitoksen henkilökunnan kanssa kahdestaan tapahtuvia tapaamisia, joten koen olevani työtä tehdessä varsin yksin ja ilman ohjaajan tukea."

Viidenneksi, sosiaalinen jännittäminen näytti vaikuttavan opiskelijan elämään myös siten, että se rajoitti mahdollisuuksia toteuttaa itseä ammatillisesti tai sosiaalisesti, kuten seuraavat aineistositaatit osoittavat. 
"Kyllä. En hakenut suoravalinnassa äidinkielen ope-linjalle."

"En osaa sanoa. Ehkä olisin voinut olla aktiivisempi laitoksen ja ainejärjestöjen toiminnassa - voisiko sanoa sosiaalisella opiskelun kentällä."

"En ole "uskaltanut" heittäytyä täysillä. Oman näkemyksen puolustaminen on tärkeää luovalla alalla, ja oman näkemyksen selittäminen muille ymmärrettävästi myös."

Sisällönanalyysi nosti esiin monia opiskelukyvyn fyysisiä ja psyykkisiä osatekijöitä. Opiskelijoiden vastauksissa arkipäivän elämää monilla tavoin haittaavat sosiaalisen jännittämisen ilmenemismuodot ja vaikutukset kietoutuivat yhteen. Sosiaalista jännittämistä ei kuitenkaan välttämättä nähdä opiskelun etenemiseen vaikuttavana tekijänä vaikka sen kerrotaan esimerkiksi aiheuttavan suurta stressiä, unettomuutta ja rajoittavan opintouraa.

\section{Toiveet avusta ongelmiin}

Korkeakouluopiskelijoiden terveystutkimuksessa opiskelijoilta kysyttiin heidän toiveitaan saada apua jännittämiseen, stressinhallintaan, ihmissuhde- tai itsetuntoasioihin sekä opiskelun ongelmiin tai opiskelutekniikkaan. Jännittämisen suureksi ongelmaksi kokevat opiskelijat toivoivat apua kaikkiin mainittuihin ongelmiin muita ryhmiä merkitsevästi yleisemmin (ks. kuvio 6). Lähes puolet niistä, jotka kokivat jännittämisen suureksi ongelmaksi, toivoi saavansa siihen apua. Apua toivottiin myös muissa kysytyissä asioissa sitä useammin, mitä voimakkaamman ongelman jännittäminen muodosti.

\section{Yhteenveto tuloksista}

Korkeakouluopiskelijat kokevat jännittämistä opiskelutilanteissa melko paljon, mutta ongelman se muodostaa vain osalle. Lievänä ongelmana jännittämisen kokee $36 \%$ miehistä ja $39 \%$ naisista ja suurena ongelmana $11 \%$ miehistä ja $17 \%$ naisista. Yleisintä ongelmaksi koettu jännittäminen oli yleisöpuhe- tai esitelmätilanteissa, vieraan kielen puhumisessa ja seminaareissa.

Tutkimus osoitti selkeästi, että ongelmaksi koettu jännittäminen on yhteydessä opiskelijoiden huonoksi kokemaan terveydentilaan ja psyykkiseen pahoinvointiin.

Korkeakouluopiskelijoiden arjessa jännittäminen ei rajoitu vain opiskelutilanteisiin, vaan on läsnä kaikessa sosiaalisessa kanssakäymisessä. Yksinäisyys, keskustelutuen puute ja opiskeluyhteisöön kuulumattomuus liittyivät jännittämisongelmaan. Myös kiusaamiskokemukset korostuivat jännittämisen ongelmaksi kokevilla. 
Toivoo apua

Jännittämisongelmissa, miehet *

Opiskelun ongelmissa tai opiskelutekniikassa,

$$
\text { miehet * }
$$
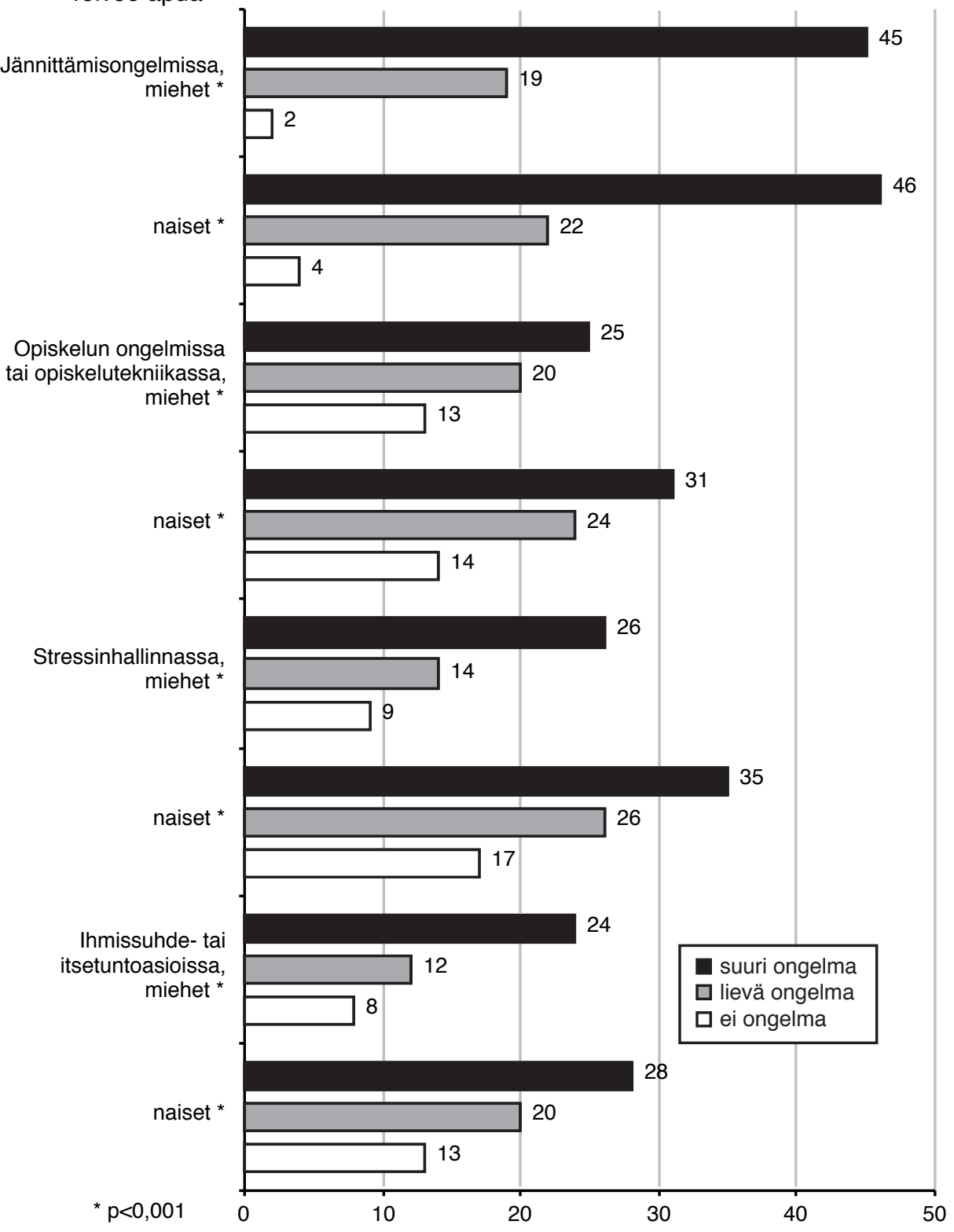

Kuvio 6. Jännittämisen yhteys toiveisiin avusta kysymyksessä "Haluaisitko apua, esim. yksilöllistä neuvontaa, ryhmäkokoontumisia, kursseja, luentoja tms. seuraavissa asioissa?" (\%). 
Opiskelun ongelmat olivat sitä yleisempiä, mitä suuremmaksi ongelmaksi jännittäminen koettiin. Opiskelu-uupumusmittari osoitti samanlaista yhteyttä jännittämisongelmaan kuin muutkin opiskelukyvyn osa-alueet. Toiveet avusta elämänhallinnan ja opiskelun ongelmissa olivat loogisia ja osoittivat opiskelijoiden tiedostavan ongelmiaan.

\section{Pohdinta}

Tutkimuksen tavoitteena oli ensinnäkin selvittää, miten yleisesti korkeakouluopiskelijat kokevat opiskelutilanteissa jännittämisen ongelmana. Toiseksi tutkimuksessa pyrittiin selvittämään ongelmaksi koetun sosiaalisen jännittämisen ja opiskelijoiden hyvinvointiin ja opiskelukykyyn vaikuttavien tekijöiden välisiä yhteyksiä. Seuraavassa pohditaan tutkimuksen keskeisiä tuloksia ja tarkastellaan niiden merkitystä opiskelijan opiskelukyvyn ja hyvinvoinnin sekä hyvinvointia varmistavien tukijärjestelmien näkökulmasta.

Tässä tutkimuksessa ongelmallista jännittämistä havaittiin enemmän kuin aiemmissa tutkimuksissa. Vertailua tosin vaikeuttaa jännittämistä kartoittavien kysymysten erilaisuus eri tutkimuksissa. Esimerkiksi Almonkarin (2007) tutkimuksessa erityisen ongelmalliseksi jännittämisen kokivat vahvasti viestintäaroiksi luokitellut yliopisto-opiskelijat, joita oli $4 \%$. Tässä tutkimuksessa jännittäminen opiskelutilanteissa oli suuri ongelma $11 \%$ :lle miehistä ja $17 \%$ :lle naisista. Tutkimuksemme suuri ja monipuolinen vastaajajoukko sekä uusi, erityyppiset opiskelutilanteet yhdistävä mittari voivat omalta osaltaan selittää tulosta.

$\mathrm{Ne}$, jotka kokivat jännittämisen lieväksi tai suureksi ongelmaksi, kokivat jännittämistä eniten yleisöpuhe- tai esitelmätilanteissa, vieraan kielen puhumisessa ja seminaareissa.

Tämä tulos noudattaa nuorten aikuisten jännittämisestä aiemmin saatuja tutkimustuloksia. Kaikenlainen jännittäminen, siis myös ei-ongelmallinen, myönteinen tms., on hyvin tavallista juuri yleisön edessä esiintyessä. SallinenKuparisen tutkimuksessa (1986) tilannekohtaista viestintäarkuutta havaittiin sellaisissa harvinaisissa esiintymistilanteissa, jotka koettiin virallisiksi, erityistaitoja vaativiksi ja yleisön arvioinnille altistaviksi. Viestintäarkuutta selittävinä tekijöitä olivat myös viestijöiden lukumäärä, puhujan saaman huomion määrä, evaluoinnin määrä ja viestintäroolin tuttuusaste (Sallinen-Kuparinen 1986, 237). Yliopisto-opintojen sekä äidinkielisissä että vieraskielisissä esitelmä- ja seminaaritilanteissa saattaa nousta esiin monia edellä mainituista tekijöistä: ne ovat opiskelijalle harvinaisia ja erityisiä, vaativiksi koettuja, suoritukset arvioidaan ja rooli niissä on ehkä uusi ja vieras. Nykypäivänä esiintyminen, vieraan kielen puhuminen ja seminaarit ovat normaaleja korkeakouluopiskelijan opiskelutilanteita. Niiden kokeminen ongelmallisiksi voi lisätä opiskelijan stressiä haitallisesti. 
Tämänkaltaisella poikkileikkaustutkimuksella voidaan osoittaa yhteyksiä, mutta ei syy-seuraussuhteita. Kuitenkin vuorovaikutus on niin tärkeä ja monimutkainen osa ihmisen elämää, että ongelma siinä heijastuu laajasti monilla osaalueilla. On osoitettu, että esimerkiksi kiusaamiskokemuksilla voi olla kauaskantoisia vaikutuksia yksilön hyvinvointiin ja vuorovaikutussuhteisiin (Pörhölä 2011). Paitsi ongelman itsessään aiheuttamaa kärsimystä ja sosiaalisen elämän kapeutumista nuoruusiän sosiaalisista peloista kärsiville saattaa kehittyä muita mielenterveyden häiriöitä, kuten masennusta, muita ahdistuneisuushäiriöitä ja päihdeongelmia ja johtaa opintojen pitkittymiseen sekä eristäytymiseen. Myös lievemmissä häiriöissä mielenterveysongelmien riski on lisääntynyt. Aikainen sosiaalisen jännittämisen tunnistaminen on siten tulevien vaikeampien ongelmien ennaltaehkäisyä. (Ranta 2008, 98-102; Merikangas ym. 2002; Ranta ym. 2001.)

Opiskelutekijöiden ja sosiaalisen jännittämisen välistä yhteyttä tarkasteltiin tässä tutkimuksessa myös opiskelijoiden itsearvioinnin perusteella. Vastauksia esittäneitä opiskelijoita ei ollut luokiteltu jännittämisen ongelmallisuuden suhteen, vaan he edustivat yhden yliopiston kolmannen, neljännen ja viidennen vuoden opiskelijoita. Vastausten tarkastelu kuitenkin osoitti, että vaikka Almonkarin (2007) mukaan opiskelijoista $76 \%$ oli sitä mieltä, että jännittäminen ei vaikuta opiskelun etenemiseen ja tutkinnon valmistumiseen, se silti vaikuttaa opiskelijan elämän laatua ja hyvinvointia heikentävästi. Jännittäminen liitettiin vastauksissa esimerkiksi unettomuuteen, stressiin, jatkuvaan huolien kokemiseen ja muun elämän rajoittumiseen. Opiskelijoiden vastausten analysointitulokset olivat samansuuntaisia kuin tilastomenetelmien avulla saadut tulokset. Voidaankin todeta, että tässä tutkimuksessa käytetyt erityyppiset aineistot täydensivät ja rikastuttivat toisiaan. Almonkarin aineiston avoimen kysymyksen laadullinen tutkimusote vahvisti tilastollisia analyysejä.

Opiskelijoiden vastausten laadullinen tarkastelu osoitti, että pelko kielteisen kokemuksen syntymisestä saa välttelemään ja lykkäämään kursseja, jotka sisältävät esiintymistä. Opiskelijat liittivät esiintymiseen monia kielteisiä ajatuksia ja tunteita. Näitä olivat esimerkiksi ahdistuksen ja stressin kokeminen, huonommuuden tunteet, pelko noloon tilanteeseen joutumisesta ja ajatus oman suorituksen huonontumisesta jännittämisen vuoksi. Nämä havainnot ovat yhdensuuntaisia aiemman tutkimuksen kanssa. Korkeakouluopiskelijoiden terveystutkimuksessa $40 \%$ opiskelijoista arvioi opiskelutilanteessa jännittämisen vaikuttavan haitallisesti ja tämä ilmenee $\mathrm{mm}$. osaamista huonompana suoriutumisena, vähäisenä keskusteluun osallistumisena, keskittymisvaikeutena tai lamaantumisena (Kunttu \& Huttunen 2009).

Opiskelijoilla oli varsin kielteinen käsitys itsestään esiintyjinä. Kielteiset odotukset, epärealistisen tulosodotukset ja toimintamallien puute saavat puhujan ennakoimaan epäonnistumista ja kuormittavat häntä henkisesti (Pörhölä 
1995, 167). Ihmisen käsitys vuorovaikutuksen luonteesta ja itsestään viestijänä voi muuttua opiskelukokemusten myötä. Myönteisesti koetun harjoittelun määrän on todettu olevan ratkaiseva tekijä opiskelijan tunnekokemuksen muodostumisessa (Finn ym. 2009). Aiemman seurantatutkimuksen mukaan esiintymisen kokeminen ongelmaksi on melko pysyvää koko yliopisto-opiskelun ajan (Kunttu ym. 2006). Kieli- ja viestintätaitojen opetuksella korkeakouluissa onkin suuri haaste: pystytäänkö opiskelijoille tarjoamaan myönteisiä harjoittelukokemuksia ja rakentavaa palautetta turvallisessa ilmapiirissä, jotta he saisivat riittävästi aineksia realistisen ja myönteisen viestijäkuvan rakentamiseen.

Tämä tutkimus osoittaa selkeästi, että ongelmaksi koettu jännittäminen on yhteydessä hyvin moniin opiskelijan hyvinvoinnin ja opiskelukyvyn osatekijöihin. Opiskelijat tarvitsevat siten apua itse jännittämisongelmaan, mutta myös muihin opiskelukyvyn osa-alueisiin, joihin jännittämisongelmat liittyvät. Apua ja tukea tulee olla eritasoista ja erityyppistä: joku tarvitsee yksilöllistä apua, toiselle vertaistuki tarjoaa paremman hyödyn. Tukea ja apua ongelmaan on toki jo saatavissakin opiskeluterveydenhuollosta, yliopistojen opintopsykologeilta sekä kielikeskusten järjestämiltä erityiskursseilta (esiintymisvarmuuden kehittäminen, jännittäjäryhmät, ks. Almonkari \& Koskimies 2004). Myös esteettömyys-toiminnassa sosiaalinen jännittäminen on huomioitu. Viime aikoina myös monissa yliopistoyhteisöissä on aloitettu opiskelijoiden hyvinvointiin tähtääviä hankkeita. On pyritty kehittämään opiskelijakeskeistä pedagogiikkaa sekä järjestetty opiskelijoille mahdollisuuksia huolehtia omasta hyvinvoinnistaan, tutustua paremmin yliopistoyhteisöön sekä oman laitoksensa henkilökuntaan.

Toiminta ei kuitenkaan ole vielä riittävän kattavaa. Moniammatillista yhteistyötä opetuksen parissa työskentelevien ja terveydenhuollon ammattilaisten välillä tulisi edelleen kehittää. Tähän päästään lisäämällä opetuksen ja koulutuksen sekä opiskeluterveydenhuollon työntekijöiden resursseja tehokkaampaan haitallisen sosiaalisen jännittämisen tunnistamiseen. Kun opiskeluterveyden, opetuksen tai esteettömyyden asiantuntijat tunnistavat ongelmaksi koettua jännittämistä, he voivat melko varmasti olettaa, että jännittämisongelma ei ole ainoa opiskelijan arkea kuormittava tekijä. Opiskelijoiden hyvinvoinnin hyväksi työskentelevät tahot, kuten opiskeluterveyden asiantuntijat sekä kielten ja viestinnän opetuksesta päättävät ovat avainasemassa, kun suunnitellaan sopivia tukimuotoja ongelmaksi koetusta jännittämisestä kärsiville opiskelijoille.

\section{Kirjallisuus}

Almonkari, M. 2007. Jännittäminen opiskelun puheviestintätilanteissa. Jyväskylän yliopisto. Jyväskylä studies in humanities 86 .

Almonkari, M. \& Koskimies, R. 2004. Esiintymisjännittäjille apua. Helsinki. Ylioppilaiden terveydenhoitosäätiön tutkimuksia 37. 
Arjas, P. 2002. Muusikoiden esiintymisjännitys. Tapaustutkimus klassisen musiikin jännittäjätyypeistä ja esiintymisvalmennuksen kurssikokemuksista. Jyväskylän yliopisto. Jyväskylä studies in the arts 82 .

Boohar, R.\& Seiler, W. 1982. Speech communication anxiety: an impediment to academic achievement in the university classroom. Journal of Classroom Interaction 18, 337-348.

Bourne, E. 1999. Vapaaksi ahdistuksesta. Työkirja paniikista ja peloista kärsiville. Helsinki: Rikurex.

Crozier, W. 2001. Understanding shyness. Psychological perspectives. Basingstoke: Palgrave.

Daly, J., McCroskey, J., Ayres, J, Hopf, . \& Ayres, D. (toim.)1997. Avoiding communication. Shyness, reticence, and communication apprehension (2. painos). Cresskill: Hampton.

Erickson, P. \& Gardner, J. 1992. Two longitudinal studies of communication apprehension and its effects on college students' success. Communication Quarterly 40, 127-137.

Finn, A., Sawyer, C. \& Schrodt, P. 2009. Examining the effect of Exposure therapy on the public speaking state anxiety. Communication Education 58 (1), 92-109.

Kunttu, K. 2008. Myös opiskelijan työkykyä on tuettava. Suomen Lääkärilehti 63 (37): 3018-3021.

Kunttu, K. 2011. Opiskelukyky. Teoksessa Kunttu K., Komulainen, A., Makkonen, K. \& Pynnönen P. (toim.) Opiskeluterveys. Porvoo: Duodecim 2011, s. 34-35.

Kunttu, K., Almonkari, M., Kylmälä. M. \& Huttunen T.2006. Yliopisto-opiskelijoiden esiintymisvarmuus ja esiintymisjännitys opiskeluterveydenhuollon näkökulmasta. Sosiaalilääketieteellinen aikakauslehti 43: 320-330.

Kunttu, K., \& Huttunen T. 2009. Korkeakouluopiskelijoiden terveystutkimus 2008. Helsinki. Ylioppilaiden terveydenhoitosäätiön tutkimuksia 45.

Kurri, E. 2006. Opintojen pitkittymisen dilemma. Tutkimus opintojen sujumattomuustekijöistä yliopistoissa ja niihin vaikuttamisen keinoista. Helsinki. Opiskelijajärjestöjen tutkimussäätiö Otus rs. 27.

Laaksonen, E. 2005. Yliopisto-opiskelijoiden psyykkinen oireilu ja siihen yhteydessä olevat tekijät. Helsinki. Ylioppilaiden terveydenhoitosäätiön tutkimuksia 38

Leary, M. \& Kowalski, R. 1995. Social anxiety. New York: Guiford.

Martin, M. 2011. Ahdistuneisuushäiriöt. Teoksessa K. Kunttu, A. Komulainen, K. Makkonen \& P. Pynnönen (toim.) Opiskeluterveys. Porvoo: Duodecim, 289-291.

McCroskey, J. 1977. Oral communication apprehension: A summary of recent theory and research. Human Communication Research 4, 78-96.

McCroskey, J. 1978. Validity of the PRCA as an index of oral communication apprehension. Communication Monographs 45, 192-203. 
McCroskey, J. 1984. Self-report measurement. Teoksessa J. Daly \& J. McCroskey (toim.), Avoiding communication. Shyness, reticence and communication apprehension. Beverly Hills: Sage.

MacIntyre, P. \& Thivierge, K. 1995. The effects of audience pleasantness, audience familiarity, and speaking contexts on public speaking anxiety and willingness to speak. Communication Quarterly 43, 456-466.

Merikangas, K.R., Avenevoli, S., Acharyya, S., Zhang, H. \& Angst J. 2002. The spectrum of social phobia in the Zurich cohort study of young adults. Biological Psychiatry 51, 81-91.

Pörhölä, M. 1995. Yksin yleisön edessä. Esiintymisjännitykseen ja esiintymishalukkuuteen liittyvät kokemukset, käyttäytymispiirteet ja vireytyminen yleisöpuhetilanteessa. Jyväskylän yliopisto. Jyväskylä studies in communication 2.

Pörhölä, M. 2011. Kouluaikaisten kiusaamiskokemusten vaikutus nuoressa aikuisiässä. Teoksessa K. Kunttu, A. Komulainen, K. Makkonen \& P. Pynnönen (toim.) Opiskeluterveys. Porvoo: Duodecim, 46-48

Pylkkänen, K. \& Repo, E. 2006. Palauttaako terapia menetetyn opiskelukyvyn. Opiskelukyky ja kuntoutus -projekti loppuraportti. Helsinki. Ylioppilaiden terveydenhoitosäätiön tutkimuksia 42.

Ranta, K., Kaltiala-Heino, R., Rantanen, P., Pelkonen, M. \& Marttunen, M. 2001. Nuorten ahdistuneisuushäiriöt. Lääketieteellinen Aikakauskirja Duodecim 117 (12), 1225-32.

Ranta, K. 2008. Social Phobia among Finnish Adolescents. Assesment, Epidemiology, Comorbidity, and Correlates. Acta Universitatis Tamperensis 1323. Tampere University Press.

Sallinen-Kuparinen, A. 1986. Finnish communication reticence. Prescriptions and self-reported behaviour. University of Jyväskylä. Studia Philologica Jyväskyläensia 19.

Salmela-Aro, K. 2009. Opiskelu-uupumusmittari SBI-9 yliopistoja ammattikorkeakouluopiskelijoille. Helsinki. Ylioppilaiden terveydenhoitosäätiön tutkimuksia 46.

Sulander, J.\& Romppanen, V. 2007. Hyvinvointi koulutyössä ja opiskelussa. Helsinki. Työterveyslaitos. Työympäristötutkimuksen raporttisarja 26.

Toskala, A. 1997. Pelot ja niiden voittaminen. Kohti uudenlaista rohkeutta. Helsinki: Writers' House.

Valkonen, T. 1995. Esiintymisjännityksen lieventäminen: rentoutuksesta visualisointiin. Teoksessa M. Valo (toim.) Haasteita puheviestinnän opetukseen. Jyväskylän yliopisto. Viestintätieteiden laitoksen julkaisuja 14, $139-153$. 